\title{
SARS-CoV-2 IMMUNITY AND AN OVERVIEW OF THE COVID-19 VACCINES
}

\section{IMUNSKI ODGOVOR NA SARS-CoV-2 I PREGLED VAKCINA PROTIV COVID-19}

\author{
Miloš Marković ${ }^{1}$
}

${ }^{1}$ Univerzitet u Beogradu, Medicinski fakultet, Institut za mikrobiologiju i imunologiju, Beograd, Srbija

Correspondence: milos.markovic@med.bg.ac.rs

\section{Abstract}

The remarkable development of a large number of vaccines against COVID-19 in a

Keywords:

COVID-19,

SARS-CoV-2,

variants,

immune response,

immunity,

vaccines,

booster,

efficiency,

effectiveness,

safety very short period of time represents one of the greatest successes of medicine and science in
history, and mass vaccination at the global level will be crucial for prevention and mitigation of COVID-19. However, there are still numerous open questions about the vaccines, and the protection they provide, and answers to those questions will not only help to control this pandemic, but they will also prepare us to react better in case of future outbreaks. This review will present the latest findings on the immune response to SARS-CoV-2 and give an update on COVID-19 immunity. It will also provide an overview of the most important vaccines against COVID-19, especially those available in Serbia, with an emphasis on their immunogenicity, efficacy and safety, as well as the platforms used for their development. In addition, a special attention will be given to open issues related to immunization against COVID-19, such as the duration of post-vaccination immunity, the degree of protection against new virus variants and the need for booster doses and mixing and matching of different COVID-19 vaccines.
Marković M. MedPodml 2021, 72(3):20-29

(C)

The authors declare no conflicts of interest. doi:10.5937/mp72-33315

Editorial board: podmladak.med.bg@gmail.com 


\section{Sažetak}

Uspešan razvoj velikog broja vakcina protiv COVID-19 u veoma kratkom perio-

Ključne reči:

COVID-19,

SARS-CoV-2,

varijante,

imunski odgovor,

imunitet,

vakcine,

revakcinacija,

efikasnost,

efektivnost,

bezbednost du predstavlja jedan od najvećih uspeha medicine i nauke u istoriji i masovna vakcinacija na globalnom nivou nesumnjivo će biti presudna za kontrolu širenja virusa SARS-CoV-2. Ipak, postoje još mnoge nedoumice u vezi sa vakcinama i zaštitom koju one pružaju i njihovo rešavanje će sigurno doprineti uspešnoj kontroli ove pandemije, ali će nas i pripremiti da bolje reagujemo u slučaju nekih budućih epidemija i pandemija. U ovom preglednom članku biće ukratko prikazana najnovija saznanja o imunskom odgovoru na SARS-CoV-2 i dat pregled najvažnijih vakcina protiv COVID-19, sa akcentom na one vakcine koje su dostupne u Republici Srbiji, pri čemu će fokus biti na njihovoj imunogenosti, efikasnosti i bezbednosti, kao i platformama na kojima su razvijene. Posebna pažnja će se dati i otvorenim pitanjima u vezi sa imunizacijom protiv COVID-19, kao što su dužina trajanja postvakcinalnog imuniteta, stepen zaštite protiv novih varijanti virusa i potreba za revakcinacijom, odnosno davanjem treće doze i eventualnim kombinovanjem različitih vakcina.

\section{Uvod}

Masovna imunizacija je ključna mera u kontroli pandemije koronavirusnog oboljenja 2019 (COVID-19) izazvanog virusom SARS-CoV-2, koja je do sredine jula 2021. godine dovela do obolevanja skoro 200 miliona i smrti najmanje 4 miliona ljudi (1). Zajednički napori naučnika i medicinskih radnika, različitih istraživačkih grupa i farmaceutskih kompanija, Svetske zdravstvene organizacije (SZO) i drugih neprofitnih medicinskih institucija, zajedno sa vladama mnogih država, doveli su do razvoja većeg broja vakcina protiv COVID-19, čija bi primena kroz globalni program vakcinacije mogla da dovede do skorog završetka pandemije i povratka sveta u tokove pre pandemije. U ovom preglednom članku biće ukratko prikazana najnovija saznanja o imunskom odgovoru na SARS-CoV-2 i dat pregled najvažnijih vakcina protiv COVID-19, sa akcentom na one vakcine koje su dostupne u Republici Srbiji. Fokus će biti na imunogenosti, efikasnosti i efektivnosti vakcina, njihovoj bezbednosti, kao i platformama na kojima su razvijene. Posebna pažnja će se dati i važnim, ali još uvek nerazjašnjenim pitanjima u vezi sa imunizacijom protiv COVID-19, kao što su dužina trajanja imuniteta nakon davanja vakcina, stepen zaštite protiv novih varijanti virusa, slabljenje imuniteta i potreba za revakcinacijom (npr. davanjem treće doze) i eventualnim kombinovanjem različitih vakcina.

\section{Imunski odgovor na SARS-CoV-2}

Novootkriveni virus SARS-CoV-2 je RNK virus sa omotačem koji ima tipičnu građu koronavirusa sa nekoliko strukturnih proteina (S, M, E i N), od kojih je šiljasti ili S ("spike") protein ključan za ulazak virusa u ćeliju (2). $S$ protein se pomoću svog domena koji vezuje receptor (engl. receptor binding domain, $\mathrm{RBD}$ ) vezuje za angiotenzin-konvertujući enzim 2 (ACE2) i inficira one ćelije u organizmu koje ga poseduju. Stoga nije iznenađujuće da S protein, a naročito njegov RBD, predstavlja glavnu metu imunskog odgovora domaćina, mada se imunski odgovor pokreće i na ostale strukturne proteine, ali i na čitav niz nestrukturnih proteina koji imaju važnu ulogu u replikaciji virusa i patogenezi infekcije izazavane SARSCoV-2. Baš neki od tih nestrukturnih proteina doprinose izbegavanju imunskog odgovora domaćina, naročito urođenog, što omogućava relativno neometanu replikaciju virusa na početku infekcije. Tako se, na primer, inhibicija ili odlaganje produkcije tipa I i III interferona, izazvana SARS-CoV-2, dovodi u vezu sa produženom inkubacijom i pojačanim inflamatornim odgovorom i posledičnim razvojem teže kliničke forme bolesti kod inficirane osobe (3). I pored važne uloge urođene imunosti, smatra se da humoralni i celularni mehanizmi adaptivne imunosti imaju presudnu ulogu u kontroli infekcije i da je adekvatan adaptivni imunski odgovor uzajamno povezan sa eliminacijom virusa i oporavkom od infekcije (4). I zaista, većina inficiranih osoba (70 - 100\%) već nekoliko dana nakon pojave simptoma ima detektabilne T-limfocite specifične za S i druge proteine SARS-CoV-2, i to kako CD4+ pomoćničke T-limfocite (pre svega Th1 ćelije), tako i CD8+ citotoksične T-limfocite, pri čemu je zapaženo da je bolji odgovor $C D 4+$ T-ćelija uzajamno povezan sa blagom kliničkom formom oboljenja, ukazujući na važnu ulogu ovih ćelija u odbrani od virusa (4). Interesantno je pomenuti da značajan broj osoba koje nisu imale COVID-19 (i do $50 \%$ u nekim studijama) ima unakrsno reaktivne T-limfocite (5), što je moguće kao odgovor na prethodni susret sa ostalim koronavirusima koji su česti uzročnici blagih respiratornih infekcija (tzv. endemski koronavirusi), ali potencijalna protektivna uloga tih ćelija nije još uvek razjašnjena. Slično T-ćelijama, nakon preležane infekcije, velika većina ljudi ima i detektabilna antitela (oko 90\% njih ih ima nakon 10 dana od infekcije), pri čemu se prvo javljaju imunoglobulin M i A (IgM i IgA) antitela, a onda IgG, mada se, iako nije uobičajeno, kod pojedinaca IgG antitela mogu detektovati u isto vreme ili čak ranije od $\operatorname{IgM}(4)$. Vrhunac produkcije antitela je posle 2 - 4 nedelje (korelira sa oporavkom), pri čemu IgM opada relativno brzo (mada nekad perzistira i mesecima), dok IgG opstaju znatno duže (mesecima, a verovatno i duže) (4). Dominantno se javljaju antitela na nukleokapsidni (N) protein (zbog čega se ta antitela rutinski detektuju u serumu ljudi u slučaju dokazivanja prethodne infekcije), ali su najvažnija anti-S antitela koja se vezuju za S protein i na taj način sprečavaju ulazak 
virusa u ćeliju, tj. neutrališu njegovu infektivnost, pri čemu je oko $90 \%$ ovih neutrališućih antitela specifično za RBD (6). Protektivna uloga neutrališućih antitela (ali i CD8+ T-limfocita) jasno je pokazana na životinjskim modelima sa nehumanim primatima (7), a smatra se da i kod ljudi ona štite od infekcije izazvane SARS-CoV-2 $(8,9)$. Treba naglasiti da količina neutrališućih antitela često korelira sa težinom kliničke slike (viši nivoi su kod onih koji su imali težu kliničku formu oboljenja), ali i da neki pacijenti (i do 10\%) koji su preležali COVID-19 (pre svega oni sa asimptomatskom infekcijom ili blagim simptomima) nemaju ili imaju veoma male detektabilne nivoe antitela (verovatno je da su i te osobe zaštićene preko T-ćelija) (4). Slično kao i kod T-limfocita, kod nekih osoba, koje nisu bile u kontaktu sa virusom SARS-CoV-2, postoje antitela koja unakrsno reaguju sa endemskim koronavirusima (kod odraslih samo oko 5\%, ali i preko $40 \%$ kod dece, u zavisnosti od uzrasta) (10). Protektivan značaj tih antitela do sada nije razjašnjen, ali je moguće da je njihovo prisustvo jedan od razloga za manje obolevanje i blažu kliničku sliku COVID-19 kod dece.

Trajanje imuniteta nakon oporavka od COVID-19

Jedno od mnogih, do sada nerazjašnjenih pitanja u vezi sa imunskim odgovorom na SARS-CoV-2 je vreme trajanja imuniteta nakon oporavka od infekcije (asimptomatske ili klinički manifestne). Na osnovu dosadašnjih saznanja, evidentno je da kod većine inficiranih antitela, ali i T-ćelije, perzistiraju najmanje 6 - 12 meseci, pri čemu je pokazano da nivoi antitela na $\mathrm{N}$ protein brže opadaju u odnosu na ona specifična za $S$ protein, odnosno da CD4+ T-ćelije opstaju duže u odnosu na CD8+ T-ćelije (npr. preko 90\% rekonvalescenata ima detektabilne CD4+ T-limfocite specifične za proteine SARS-CoV-2 nakon 6 meseci) $(4,11,12)$. Primećeno je i da se opadanje nivoa antitela dešava $u$ dve faze, $u$ kojima je incijalno brz pad praćen fazom sporijeg opadanja (12). Od naročitog interesa je činjenica da SARS-CoV-2 kod ljudi indukuje snažan memorijski odgovor i da su memorijski T- i B-limfociti, ali i dugoživeće plazma ćelije detektabilni kod mnogih ljudi i do 11 meseci nakon oporavka od COVID-19 (11-15). Za procenu dužine trajanja imuniteta može da se koristi i analogija sa ostalim koronavirusima, pri čemu je poznato da kod osoba koje su imale SARS ili MERS antitela traju najmanje 1 - 2 godine (kod pojedinaca i do 17 godina), a T-ćelije i duže (nekad i preko 10 godina), dok je kod endemskih koronavirusa moguće da je trajanje imuniteta kraće s obzirom na to da je primećeno da se dešavaju reinfekcije istim virusom već sledećih sezona $(15,16)$. Vreme će pokazati u kojoj meri imunski odgovor na SARS-CoV-2 korelira sa odgovorima na ostale koronaviruse, ali je već sada izvesno da će imunitet kod većine rekonvalescenata biti relativno dugotrajan. U prilog tome govore rezultati opservacionih studija koje pokazuju da je između $80 \%$ i 90\% ljudi koji su preležali COVID-19 zaštićeno od ponovne infekcije nakon $6-7$ meseci od oporavka $(17,18)$.
Iz svega navedenog proizilazi da bi vakcine, pod uslovom da indukuju sličan imunski odgovor kao i sam virus SARSCoV-2, mogle uspešno i dugotrajno da zaštite vakcinisane osobe od COVID-19 i rezultati studija akumulirani tokom poslednjih 7 meseci od početka primene vakcina pokazuju da je to verovatno tako, o čemu će i biti reči u preostalom delu ovog rada.

\section{Imunizacija protiv COVID-19}

Cilj imunizacije protiv COVID-19 je da zaštiti vakcinisane osobe od klinički manifestne, simptomatske bolesti i to, pre svega, od teških formi COVID-19 i na taj način spreči njene eventualne komplikacije i smrtni ishod, a po mogućstvu da spreči i samu infekciju virusom SARS-CoV-2 i razvoj asimptomatske infekcije, čime bi bilo onemogućeno prenošenje virusa na drugu osetljivu osobu. Drugim rečima, vakcine treba da indukuju dobar i dugotrajan imunitet koji efikasno štiti od bolesti, a da su pri tome bezbedne. U tom smislu, a u skladu sa prethodno navedenim saznanjima o imunskom odgovoru na SARS-CoV-2, jasno je da vakcine, da bi bile efikasne protiv COVID-19, treba da indukuju neutrališuća antitela na $S$ protein (eventualno i antitela na druge antigene virusa), ali i celularnu imunost posredovanu kako pomoćničkim CD4+ T-ćeljama (pre svega Th1 ćelijama), tako i citotoksičnim CD8+ T-limfocitima specifičnim za S- i druge proteine virusa, pri čemu je važno da se postigne i indukcija dugoročne memorije kroz stvaranje memorijskih T- i B-limfocita i dugoživećih plazma ćelija. Stoga nije iznenađujuće što sve vakcine koje su u upotrebi ili u razvoju kao glavni antigen sadrže S protein ili RBD kojim se on vezuje za receptore na ćelijama, $s$ tim što neke vakcine sadrže i druge antigene (npr. inaktivisane vakcine koje sadrže cele ubijene viruse). Za indukciju protektivnog imuniteta vakcina važni su i način njihovog davanja i broj datih doza. Većina do sada razvijenih vakcina daje se parenteralnim putem (najčešće intramuskularnim, a ređe supkutanim ili intradermalnim putem) i sve vakcine protiv COVID-19, koje su u ovom trenutku u upotrebi, daju se intramuskularno, čime se indukuje stvaranje pre svega specifičnih IgG antitela. Ipak, s obzirom na to da se radi o respiratornom patogenu, intranazalno davanje preko nosne sluzokože bilo bi veoma korisno, ne samo zbog praktičnosti takvog načina davanja nego i zbog činjenice da na taj način može da se indukuje produkcija IgA antitela u mukozi disajnih puteva, a moguće čak i rezidentnih memorijskih T-limfocita (19). Veći broj kliničkih studija sa vakcinama koje se daju mukoznim putem je u toku, tako da je realno pretpostaviti da će se u upotrebi uskoro pojaviti neka takva vakcina (19). Takođe, za većinu vakcina za SARS-CoV-2 predviđeno je da se daju u dve doze, sa izuzetkom nekih vektorskih vakcina koje se za sada daju u samo jednoj dozi (20), ali je verovatno da će se u skorijoj budućnosti uvesti i treća doza i takve preporuke već postoje u pojedinim zemljama uključujući i Srbiju (21), a klinička ispitivanja koja se bave tim pitanjem kod različitih vakcina su u toku (videti kasnije u tekstu). 


\section{Razvoj vakcina protiv COVID-19}

Do sada razvijene vakcine protiv COVID-19 bazirane su na različitim platformama (22), od konvencionalnih „tradicionalnih“ pristupa, kao što inaktivisane vakcine koje su decenijama u upotrebi (npr. vakcine protiv gripa ili poliomijelitisa), preko novijih platformi koje su već primenjene kod nekih vakcina, kao što su vakcine koje sadrže antigene patogena dobijene tehnologijom rekombinantne DNK (npr. vakcine protiv hepatitis B virusa i humanih papiloma virusa), a u nekoj meri i vektorske vakcine (npr. vakcine protiv Ebole), do inovativnih platformi koje do sada nisu korišćene u registrovanim vakcinama, kao što su RNK i DNK vakcine. Konvencionalne vakcine imaju mnoga ograničenja koja naročito dolaze do izražaja u uslovima velikih epidemija i pandemija, kao što je slučaj sa trenutnom pandemijom izazvanom SARS-CoV-2. Na primer, za njihovu proizvodnju su neophodni kultivacija i umnožavanje patogena, za šta je potrebno obezbediti visok stepen bezbednosti u laboratorijama, kapacitet za proizvodnju velikog broja vakcina je relativno ograničen, a razvoj ovih vakcina obično dugo traje i prilično je skup (23). Takođe, inaktivisane i subjedinične vakcine indukuju pre svega produkciju antitela i imaju slabiju imunogenost (što se može u nekoj meri kompenzovati davanjem većeg broja doza i dodavanjem adjuvansa). Nasuprot kovencionalnim, inovativne platforme su bazirane na potpuno različitom principu u kojem se, umesto patogena (živog ili mrtvog) ili nekog njegovog dela/produkta, osoba imunizuje tako što se vakcinom unosi informacija, u vidu DNK ili informacione RNK (iRNK), za određene proteine patogena ili njihove delove (obično one koje sadrže imunodominantne epitope), a potom same ćelije domaćina produkuju te antigene patogena i sledstveno pokreću imunski odgovor. Ovakav pristup ima mnoge prednosti, naročito u uslovima pandemije, kao što su relativno jednostavan dizajn i mogućnost brzog razvoja i proizvodnje velikih količina ovih vakcina (najčešće se radi o sintetičkim vakcinama koje ne zahtevaju kultivaciju i propagaciju patogena), relativno niska cena, višestruka mogućnost primene (npr. samo promenom sekvence gena patogena moguće je dobiti novu vakcinu), nekada uz korišćenje istih proizvodnih kapaciteta. Treba posebno istaći da su vakcine bazirane na ovim platformama veoma imunogene i da kod vakcinisanih osoba indukuju snažan imunski odgovor, kako humoralni, tako i celularni (22). I pored nesumnjivih prednosti, ove nove platforme imaju i neka ograničenja. Na primer, kod vektorskih vakcina postojanje imuniteta kod vakcinisane osobe na vektor (npr. adenoviruse koji često izazivaju blage respiratorne infekcije kod ljudi) ili razvoj imuniteta na vektor nakon prve doze mogu značajno da oslabe odgovor na vakcinu (naročito nakon druge doze ili revakcinacije) i smanje efikasnost ovih vakcina. S druge strane, vakcine bazirane na nukleinskim kiselinama imaju druga ograničenja, kao što je, na primer, nestabilnost RNK molekula i potreba za njihovim čuvanjem na veoma niskim temperaturama, što značajno otežava transport i distribuciju RNK vakcina ili teškoće da DNK koja nosi informaciju za imunodominantne epitope patogena dospe u jedro ćelije vakcinisane osobe, što značajno komplikuje primenu DNK vakcina (23). Bez obzira na ta ograničenja, korišćenje ovih novih naprednih tehnologija bilo je od presudnog značaja za brzi razvoj vakcina protiv COVID-19 (24). Tome su doprineli i udruživanje velikog broja istraživačkih grupa i farmaceutskih kompanija i velika finansijska podrška vlada razvijenih država i neprofitnih organizacija, a naročito činjenica da se u razvoju ovih vakcina nije „krenulo od nule“ već da je prethodno postojala velika količina akumuliranih podataka iz naučnih studija i nekoliko kandidata za vakcine za SARS i MERS, viruse srodne SARS-CoV-2, koji takođe mogu da izazovu teške respiratorne infekcije (25). Kao rezultat svega toga, razvijen je veliki broj vakcina protiv SARS-CoV-2 u veoma kratkom periodu od 12 do 18 meseci, što je do sada nezabeleženo u istoriji medicine. Naime, prema podacima SZO, sredinom jula u svetu je u razvoju bilo preko 290 kandidata vakcina protiv COVID-19, od kojih se 108 vakcina već nalazi u kliničkim studijama, a za čak 33 vakcine (4 RNK vakcine, 5 vektorskih, 10 inaktivisanih, 11 subjediničnih i 3 DNK vakcine) u toku je faza 3 kliničkih ispitivanja ili je već završena (26). Štaviše, preko 15 vakcina je već uvedeno u upotrebu u različitim zemljama u svetu (sedam od njih je odobreno za upotrebu i od strane SZO), što je omogućilo da se započne sa masovnom imunizacijom protiv COVID-19 $(27,28)$. Kao rezultat toga, od decembra 2020. godine, kada su data prva odobrenja za upotrebu vakcina u uslovima pandemije, pa do sredine jula 2021. godine, dato je preko 3,5 milijarde doza vakcina $(1,27)$. Ipak, zbog ograničenog prostora, fokus u daljem tekstu će biti na onim vakcinama koje su već u upotrebi u Republici Srbiji ili čije se uvođenje u upotrebu uskoro očekuje. Naime, Agencija za lekove i medicinska sredstva Srbije (ALIMS) je krajem 2020. godine registrovala prvu vakcinu protiv SARS-CoV-2 u Srbiji. Radi se o BNT162b2 (Comirnaty ${ }^{\oplus}$, Pfizer-BioNTech), razvijenoj na platformi iRNK (29). Nedugo nakon toga, u periodu do početka februara 2021. godine, registrovane su još tri vakcine, inaktivisana vakcina BBIBP-CorV (Vero Cell ${ }^{\circ}$, Sinopharm) i vektorske vakcine Gam-COVID-Vac (Sputnik V', Gamaleya Institute) i ChAdOx1 nCoV-19 AZD1222 (Vaxzevria ${ }^{\circ}$, University of Oxford/AstraZeneca). Konačno, očekuje se uskoro da preko globalnog programa COVAX pod pokroviteljstvom SZO u Srbiju stigne još jedna RNK vakcina, odnonso mRNA-1273 vakcina (Spikevax, Moderna) (30).

\section{Efikasnost i efektivnost dostupnih vakcina protiv COVID-19}

Prve vakcine za koje su objavljeni rezultati faze 3 kliničkih studija bile su dve RNK vakcine, BNT162b2 i $m R N A-1273(31,32)$, na osnovu kojih su regulatorna tela $\mathrm{SAD}$, Velike Britanije i mnogih drugih zemalja dale uslovno odobrenje za njihovu upotrebu u uslovima ugroženog javnog zdravlja pandemijom. Ove vakcine su razvijene na istoj platformi i sadrže iRNK koja kodira celokupan S protein u prefuzionoj konformaciji koji je veoma imunogen, pri čemu je iRNK smeštena u lipidnu nanočesticu, čime 
je obezbeđeno da iRNK lakše prodre u citoplazmu ćelija vakcinisane osobe, a da pritom ne bude razgrađena od strane enzima koji su prisutni u tkivima. Obe vakcine se daju u dve doze (druga nakon 21 dan za BNT162b2, odnosno nakon 28 dana za $m R N A-1273)$ i obezbeđuju visok stepen zaštite. Naime, efikasnost BNT162b2 vakcine u zaštiti od simptomatske bolesti bila je u studiji $95 \%$, dok je kod $m R N A-1273$ vakcine efikasnost iznosila $94,1 \%$, pri čemu je i zaštita protiv teških formi bolesti bila izuzetno visoka. Inače, određeni stepen zaštite je kod obe vakcine mogao da se uoči već od 12. dana nakon prve doze, pri čemu je puna zaštita ostvarena nedelju dana nakon druge doze vakcine. S obzirom na to da RNK vakcine do sada nisu nikada korišćene u humanoj populaciji (osim u manjim kliničkim studijama), ovako slični rezultati dobijeni sa dve različite vakcine $\mathrm{u}$ dve različite kliničke studije sa velikim brojem ispitanika (od 30 do 40 hiljada) nedvosmisleno su pokazali da su RNK vakcine efikasne u indukciji protektivnog imuniteta protiv COVID-19 $(31,32)$.

Ubrzo nakon dobijanja rezultata studija sa RNK vakcinama, objavljeni su i rezultati faza 3 kliničkih studija za dve vektorske vakcine, ChAdOxl nCoV-19 i Gam-COVIDVac (33-35). Obe vakcine su razvijene na platformama zasnovanim na adenovirusnim vektorima koji nose informaciju za ekspresiju S proteina SARS-CoV-2, a genetskom modifikacijom su izmenjeni tako da ne mogu da se replikuju u ćelijama vakcinisane osobe. Naučnici koji su dizajnirali ove vakcine pribegli su različitim pristupima s ciljem da izbegnu mogućnost da postojeći imunitet kod vakcinisanih osoba smanji efikasnost ovih vakcina. Kod ChAdOxl-S/ $n C o V-19$ vakcine je kao vektor iskorišćen adenovirus šimpanze koji normalno ne kruži u humanoj populaciji, a kod Gam-COVID-Vac su korišćeni humani adenovirusi, ali različiti tipovi za prvu (adenovirus 26) i drugu dozu vakcine (adenovirus 5). Zahvaljujući takvim pristupima, u studijama faze 3 je dobijena značajna efikasnost ovih vakcina koja je za ChAdOx1 $n C o V-19$ vakcine iznosila u proseku između $70 \%$ i $76 \%$ (u različitim studijama se kretala između $62 \%$ i $90 \%)(35,36)$, a kod Gam-COVID-Vac, s obzirom na heterologi "prime/boost" režim, dostignuta je zavidna efikasnost od čak $91,6 \%$, pri čemu se zaštita mogla detektovati već 16 18 dana nakon prve doze (33). U pomenutim studijama je pokazano da je zaštita od teške forme bolesti kod obe vakcine bila potpuna. Interesantno, kod ChAdOx1 nCoV-19 vakcine je primećeno da efikasnost raste ako se druga doza odloži (aplikuje se u dužem vremenskom razmaku u odnosu na prvu dozu), tako da je preporuka u mnogim zemljama, uključujući i preporuke SZO, da se druga doza daje nakon 8-12 nedelja posle prve doze $(37,38)$. Treba naglasiti da obe vakcine obezbeđuju i značajan stepen zaštite nakon samo jedne doze i da se razmatra mogućnost da se u uslovima nedovoljne dostupnosti vakcina za imunizaciju na globalnom planu koristi samo jedna doza $(37,39)$, kao što je slučaj i sa još jednom vektorskom vakcinom, Ad26.COV2.S (JßJ/ Janssen), koja se daje u samo jednoj dozi (20), ali ova vakcina za sada nije registrovana za upotrebu u Srbiji.

Nedavno su objavljeni i rezultati faze 3 kliničke studije za inaktivisanu vakcinu BBIBP-CorV (40), koju je u
Srbiji do sada primio najveći broj ljudi. Radi se o vakcini razvijenoj na konvencionalnoj platformi zasnovanoj na kultivaciji virusa u ćelijskoj kulturi (Vero ćelije) i njegovoj inaktivaciji pomoću $\beta$-propiolaktona (41). Efikasnost ove vakcine, koja je dobijena u studiji, kretala se između $72 \%$ i $78 \%$ (u zavisnosti od ispitivane grupe), s tim što je potrebno naglasiti da je u studiji bilo veoma malo ispitanika starijih od 60 godina i da su zabeležena samo dva slučaja teže bolesti kod ispitanika (40), tako da efikasnost ove vakcine kod starije populacije nije nedvosmisleno pokazana. Ipak, rezultati nedavno sprovedene opservacione studije iz Bahreina ukazuju na to da je stepen zaštite koju daje ova vakcina kod starijih uporediv sa onim kod mlađih (42).

Iako su studije faze 3 pokazale da je efikasnost svih vakcina u zaštiti od simptomatske COVID-19 prilično visoka i znatno prevazilazi minimalnu granicu od 50\%, definisanu od strane SZO i nekih regulatornih tela (43), postavlja se pitanje njihove efektivnosti, odnosno u kojoj meri one štite od bolesti nakon njihove implementacije i masovne primene u opštoj populaciji. Rezultati opservacionih studija obavljeni u nekoliko zemalja nakon početka davanja nekih od vakcina protiv SARS-CoV-2 virusa ukazuju na to da je efektivnost tih vakcina vrlo slična nivoima efikasnosti koji su prijavljeni u fazama 3 kliničkih ispitivanja, pokazujući da su ove vakcine zaista efikasne u zaštiti ljudi od simptomatskih formi COVID-19, hospitalizacije i smrtnih ishoda i u „stvarnom životu“. Ovakvi rezultati su, za sada, dostupni uglavnom za RNK vakcine (44-48), a u manjoj meri za neke vektorske vakcine, pre svega ChAdOx1 $n$ CoV-19 $(45,48)$. Tako, na primer, podaci iz Izraela ukazuju da dve doze BNT162b2 vakcine obezbeđuju između $87 \%$ i $100 \%$ zaštite od različitih kliničkih formi i ishoda simptomatske COVID-19, u zavisnosti od uzrasta vakcinisanih osoba $(46,47)$. Štaviše, pokazalo se da ova vakcina u velikoj meri štiti i od asimptomatske infekcije, u rasponu od 80\% nakon jedne doze, do čak 90 - 93\% nakon dve doze vakcine $(47,49)$, što može veoma značajno da utiče na sprečavanje prenošenja (cirkulaciju) virusa u populaciji. Takođe je pokazano da u slučaju infekcije vakcinisane osobe produkuju značajno manju količinu virusa od nevakcinisanih i na taj način se smanjuje mogućnost prenosa virusa sa vakcinisane na osetljivu osobu (50). Ipak, treba pomenuti da se uporedo sa pojavom „delta soja“ SARS-CoV-2 pojavljuju izveštaji iz nekih zemalja (npr. iz Izraela, ali ne i Velike Britanije) da nakon nekoliko meseci efektivnost BNT162b2 opada, mada je i dalje evidentan visok stepen zaštite od težih formi bolesti $(51,52)$. Podaci o efektivnosti drugih vakcina, uključujući i one koje su upotrebi u Srbiji (BBIBP-CorV i Gam-COVID-Vac) još uvek su vrlo ograničeni, ali postoje nagoveštaji da je njihova efektivnost takođe visoka i da prelazi $90 \%$, naročito kada su u pitanju teže forme COVID-19 (53). S druge strane, treba pomenuti da postoje i podaci da u nekim zemljama gde su korišćene inaktivisane vakcine postoji značajan porast broja slučajeva COVID-19 uprkos visokom obuhvatu imunizacijom (54). U zaključku, očigledno je sve više dokaza koji ukazuju da sve dostupne vakcine protiv COVID-19 obezbeđuju veoma dobru zaštitu od klinički 
manifestne bolesti, naročito od njenih težih formi sa neizbežnom hospitalizacijom i mogućim smrtnim ishodom, a postoje naznake da barem neke od njih u priličnoj meri štite i od asimptomatske infekcije SARS-CoV-2.

Imunogenost i bezbednost dostupnih vakcina protiv COVID-19

Sve vakcine protiv COVID-19 su u znatnoj meri imunogene, što je uglavnom pokazano u fazama $1 \mathrm{i} / \mathrm{ili} 2 \mathrm{kli}-$ ničkih studija (55-60), ali je sve više dostupnih radova u kojima se analiziraju imunski odgovori kod vakcina i nakon početka njihove primene (61-63). Očekivano, sve vakcine indukuju antitela na $S$ protein, uključujući i neutrališuća antitela (kod nekih vakcina su nivoi antitela viši u odnosu na rekonvalescente), pri čemu inaktivisane vakcine indukuju i druga antitela (npr. na N protein) (55). Većina vakcina indukuje celularni odgovor, s tim što je uglavnom ispitivan odgovor CD4+ T-ćelija, a u manjoj meri i CD8+ T-ćelija (55). Ipak, treba naglasiti da postoji velika metodološka heterogenost među do sada sprovedenim studijama i da, $u$ odsustvu definisanih protektivnih nivoa antitela (tzv. korelata protekcije) i u nedostatku rezultata studija kojima bi se poredila imunogenost različitih vakcina (tzv. "head-to-he-

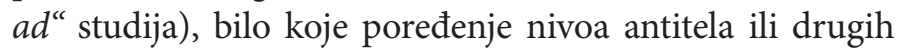
imunoloških markera nakon vakcinacije nema mnogo stručnog opravdanja u cilju procene i međusobnog poređenja imunogenosti različitih vakcina protiv COVID-19 (55).

Što se tiče bezbednosti vakcina protiv COVID-19 koje su do sada u upotrebi, sve ove vakcine su pokazale izuzetno dobar bezbednosni profil u kliničkim ispitivanjima (31-34,40). Visoka bezbednost ovih vakcina je potvrđena i nakon njihovog uvođenja u upotrebu i datih više stotina miliona doza u velikom broju zemalja, uključujući i one sa dobro razvijenim sistemom za nadzor i prijavljivanje neželjenih događaja nakon imunizacije (64-66). Za većinu vakcina protiv COVID-19 je karakteristična relativno izraženija reaktogenost, naročito u slučaju RNK i vektorskih vakcina, pri čemu su reakcije bile izraženije nakon druge doze, osim kod vektorskih (npr. ChAdOx1 nCoV-19), kod kojih je veća reaktogenost ispoljena nakon prve doze Nakon davanja vakcina dominiraju lokalne reakcije (bol i crvenilo, a u manjoj meri otok i drugo), ali su relativno učestale i sistemske reakcije u vidu povišene telesne temperature, jeze, glavobolje, malaksalosti itd. Veoma retko su registrovane teže alergijske reakcije nakon primene vakcina protiv COVID-19. Ipak, sve te reakcije su bile privremenog karaktera i prolazile se posle nekoliko dana bez posledica, dok su dugotrajnije i teže neželjene reakcije, uključujući i miokarditis i perikarditis (nakon primene RNK vakcina) ili tromboembolijske događaje (nakon primene vektorskih vakcina), bile veoma retke i u najvećem broju slučajeva njihova učestalost nije bila veća u odnosu na učestalost nabrojanih stanja u opštoj nevakcinisanoj populaciji, tako da uzročno-posledična povezanost tih događaja sa vakcinama, iako moguća, nije direktno dokazana (65-68). Na primer, nakon davanja nekih vektorskih vakcina veoma retko može da javi tromboza u kombinaciji sa trombocitopenijom (engl. thrombosis with thrombocytopenia syndrome, TTS) koja može da ima i letalan ishod i na osnovu do sada dostupnih podataka procenjuje se da je učestalost ovog sindroma na nivou od jednog do nekoliko slučajeva na 100.000 vakcinisanih osoba (66-68), a predloženi su i potencijalni patogenetski mehanizmi koji uključuju aktivaciju trombocita antitelima za koje se pretpostavlja da bi mogli da dovedu do razvoja ovog sindroma $(68,69)$. Kao rezultat takve opservacije, regulatorna tela i stručni komiteti nekih zemalja su privremeno ili trajno obustavili davanje ovih vakcina za određene grupe ljudi, ali je generalni stav SZO i Evropske agencije za lekove (EMA) da korist od ovih vakcina premašuje potencijalni rizik njihove primene, naročito u uslovima nedovoljno dostupnih vakcina, te SZO i EMA i dalje preporučuju njihovo korišćenje za imunizaciju ljudi u cilju prevencije COVID-19, uz neophodnost daljeg pomnog praćenja neželjenih reakcija $(67,70)$.

\section{Da li vakcine štite protiv varijanti SARS-CoV-2?}

Vakcine koje su sada dostupne zasnovane su na prvoj SARS-CoV-2 genomskoj sekvenci (Wuhan-1) koja je objavljena od strane kineskih naučnika (71) ili genetski blisko povezanim virusima sa drugih lokacija (19). Sve te vakcine su pokazale visok stepen efikasnosti protiv tih varijanti virusa, uključujući i one koji su imali aminokiselinsku supstituciju $D 614 G$, a koje su u prvim mesecima pandemije bile preovlađujuće (72). Ipak, tokom poslednjih meseci su se u različitim delovima sveta pojavile varijante SARSCoV-2, među kojima se posebno ističu četiri varijante za brigu (engl. variant of concern) (73), nedavno preimenovane u alfa, beta, gama i delta (74), koje imaju dodatne mutacije u svom genomu (a naročito u delu koji kodira RBD S proteina). Za neke od tih mutacija (npr. one koje dovode do aminokiselinskih supstitucija, kao što su E484K i L452R) pokazano je da mogu da dovedu do smanjenog protektivnog kapaciteta neutrališućih antitela i/ili celularne imunosti nakon preleźane bolesti ili vakcinacije $(75,76)$, a što bi moglo da ciovecie 1 do posledičnog smanjenja efektivnosti do sada primenjenih vakcina u prevenciji COVID-19. Sve je više dostupnih rezultata iz radova koji analiziraju kapacitet seruma osoba vakcinisanih različitim vakcinama da neutrališu navedene varijante virusa i njihova detaljna analiza prevazilazi obim ovog rada. Ipak, generalno deluje da sve vakcine štite u priličnoj meri od alfa varijante, a nešto manje od beta, a moguće i gama varijante (nema mnogo dostupnih podataka za nju) i da je zaštita od teških kliničkih formi bolesti uzrokovanih ovim varijantama veća u poređenju sa zaštitom od blage do umerene bolesti ili asimptomatskih formi COVID-19 (19,77-79). Među „zabrinjavajućim“ varijantama posebno se ističe delta varijanta, koja se prvi put pojavila u Indiji krajem 2020. godine, ali se zbog povećanog kapaciteta za prenošenje, tj. manje infektivne doze $\mathrm{u}$ odnosu na ostale varijante SARS-CoV-2 (po procenama čak 40 - 60\% više u odnosu na alfa varijantu), brzo proširila i postala dominantna u mnogim zemljama širom sveta, uključujući i mnoge evropske zemlje, te se postavlja pitanje u kojoj meri vakcine štite i od ove varijante virusa (80). $\mathrm{Na}$ 
osnovu dostupnih podataka, iako je neutrališući kapacitet antitela protiv ove varijante nešto snižen (posebno nakon jedne doze), smatra se da su kompletno vakcinisane osobe u velikoj meri zaštićene od razvoja COVID-19 i to naročito od težih kliničkih manifestacija i potrebe za hospitalizacijom, odnosno od nepovoljnih ishoda bolesti (52,62,81-83). Ipak, postoje nagoveštaji da vakcinisane osobe, ako su izložene delta soju, mogu da obole, pa čak i da prenesu infekciju i da je količina virusa koju one produkuju uporediva sa količinom virusa prisutnom kod nevakcinisanih osoba (84), ali je potreban veći broj studija da to nedvosmisleno potvrdi. U svakom slučaju, treba naglasiti da postoji realna mogućnost da će u budućnosti postojeće vakcine protiv COVID-19 morati da budu izmenjene u smislu da će sadržati neke od ovih ili budućih varijanti, ali će se takve odluke doneti na osnovu nadzora praćenja kruženja tih varijanti virusa u humanoj populaciji i pojave obolevanja (naročito težih formi bolesti) kod vakcinisanog dela populacije, što će zahtevati sinhronizovanu aktivnost na globalnom nivou. Sličan pristup je već poznat za vakcinu protiv gripa, za koju se pred svaku aktuelnu sezonu „komponuje“ nova vakcina sa dominantnim podtipovima virusa gripa registrovanih na Južnoj, odnosno Severnoj hemisferi (85).

Trajanje postvakcinalnog imuniteta i potreba za davanjem dodatnih doza i/ili kombinovanjem vakcina

Jedno od ključnih i za sada nerazjašnjenih pitanja je koliko traje zaštita od COVID-19 nakon vakcinacije. S obzirom na kratko vreme proteklo od početka davanja ovih vakcina, razumljivo je da u ovom trenutku nije moguće precizno proceniti koliko će da traje postvakcinalni imunitet. Ipak, pošto vakcine indukuju neutrališuća antitela na $S$ protein, verovatno je da će se nivoi antitela nakon vakcinacije ponašati slično obrascima primećenim nakon preležane infekcije, sa sličnom kinetikom njihovog opadanja (kao što je navedeno ranije u tekstu), tako da je realno očekivati, barem za neke vakcine, da zaštita nakon vakcinacije traje relativno dugo. $U$ tom smislu, interesantno je naglasiti da je $u$ jednoj studiji procenjeno da je za zaštitu vakcinisane osobe od simptomatske bolesti dovoljno $20 \%$, a od teške forme bolesti samo 3\% od prosečnog nivoa tih antitela prisutnih kod rekonvalescenata (61). Ono što je za sada poznato iz studija praćenja kod primene RNK vakcina je da visoki nivoi antitela perzistiraju najmanje 6 - 7 meseci nakon vakcinacije (86) i da je stepen zaštite od COVID-19 još uvek iznad 90\% (87), dok za ostale vakcine podaci još uvek nisu dostupni, mada se i kod njih procenjuje da bi zaštita mogla da bude dugotrajna.

$\mathrm{U}$ vezi sa trajanjem postvakcinalnog imuniteta $\mathrm{i}$ eventualnog izbegavanja imuniteta od strane novih varijanti SARS-CoV-2, logično se postavlja i pitanje potrebe za davanjem dodatnih, tzv. "booster" doza, odnosno revakcinacije (pitanje treće doze i/ili sezonskog vakcinisanja svake godine, kao kod zaštite od gripa). Mada se u mnogim zemljama prijavljuju sporadični slučajevi pojave bolesti kod vakcinisanih osoba, pri čemu se neki od njih povezuju sa varijantama SARS-CoV-2 virusa (88), rezultati manjeg broja studija i zvaničnih izveštaja koji postoje o tome ukazuju na to da se obolevanje vakcinisanih ne dešava češće nego što je to očekivano na osnovu efikasnosti dobijene u kliničkim studijama i da vakcine i dalje veoma dobro štite, naročito od teške forme bolesti $(89,90)$. Tako, na primer, podaci iz SAD, gde je velika većina stanovništva vakcinisana nekom od RNK vakcina, pokazuju da je zanemarljivo mali broj vakcinisanih (nešto preko $5.000 \mathrm{od}$ 159 miliona vakcinisanih) razvio težu formu COVID-19 i bio hospitalizovan, sa retkim smrtnim ishodom i to prevashodno kod obolelih starijih od 65 godina (91). U svakom slučaju, strategija koje se odnosi na davanje treće doze (i eventualno naknadnih doza) mogla bi da podrazumeva davanje vakcine koja je identična kao i prethodno data ili davanje modifikovane vakcine koja sadrži neku novu varijantu (moguće su i bi- i multivalentne vakcine sa više varijanti), ali bi takođe mogla da podrazumeva i davanje neke druge vakcine, napravljene na istoj ili različitoj platformi (heterologi "prime/boost" režim). Takav pristup sa kombinovanjem vakcina ne samo da je praktičan (pogotovu u uslovima nedovoljnog broja dostupnih vakcina) već je moguć i potencijalno širi/bolji imunski odgovor i jači "boost" efekat (92). U svakom slučaju, za donošenje takvih odluka ključni su rezultati studija i poznato je da je veći broj studija u toku i da se u mnogima od njih prate efekti kombinovanja različitih vakcina (npr. Com-COV studija u V. Britaniji i CombivacS studija u Španiji), naročito u svetlu pojave TTS kod osoba koji su primili ChAdOx1 nCoV-19 vakcinu kao prvu dozu i pomenutog obustavljanja njenog davanja. Prvi dostupni rezultati iz pomenutih studija ukazuju da kombinovanje vakcina indukuje snažan imunski odgovor, koji je nekada i jači u odnosu na davanje iste vakcine, uz, u nekim slučajevima, povišenu reaktogenost, ali bez težih neželjenih reakcija (93-96). Naravno, jedno od važnih pitanja je i ko i kada bi trebalo da bude revakcinisan i u tom smislu faktori koji bi mogli da utiču na donošenje takve odluke bi bili procena rizika pojedinca od infekcije, njegov imunološki status i postojanje komorbiditeta, postvakcinalni nivoi antitela u populaciji, dostupnost vakcina i tako dalje, i očekuje se da studije koje su u toku obezbede rezultate koji bi pomogli u selekciji kandidata za davanje "booster"doze(a).

Otvorena pitanja i dalje perspektive u razvoju vakcina protiv COVID-19

Uspešan razvoj velikog broja vakcina protiv COVID-19 u veoma kratkom periodu (godinu i po dana) evidentno je jedan od najvećih uspeha medicine i nauke $\mathrm{u}$ istoriji i masovna imunizacija na globalnom nivou nesumnjivo će biti presudna za kontrolu infekcije virusom SARS-CoV-2. Ipak, postoje još mnoga otvorena i nerazjašnjena pitanja u vezi sa vakcinama protiv COVID-19 i zaštitom koju pružaju, kao što su, na primer, uticaj vakcina na smanjenje prenošenja virusa SARS-CoV-2, pitanja efektivnosti vakcina u posebnim grupama (npr. kod 
imunodeficijentnih osoba), definisanje korelata protekcije, trajanje i slabljenje imuniteta i potreba za "booster" dozama (revakcinacijama), dalja evolucija virusa i njegova varijabilnost usled mutacija i posledična mogućnost gubitka efektivnosti raspoloživih vakcina, ali i pitanje kolektivnog imuniteta - koliki je dovoljan, da li i kada je dostižan i šta je za to potrebno. Takođe, pandemija COVID-19 je razotkrila ogromnu nejednakost $\mathrm{u}$ dostupnosti zdravstvene zaštite i pristupu vakcinama tako da, i pored velikih napora SZO i mnogih država, još uvek postoje problemi u samoj implementaciji programa vakcinacije povezanih sa neravnomernom raspodelom vakcina i nedovoljnim kapacitetima za proizvodnju. Konačno, negativan uticaj snažnog antivakcinalnog pokreta globalno, prisustvo različitih neutemeljnih mitova i teorija zavere u javnom prostoru i posledična rezervisanost značajnog broja ljudi da primi vakcinu, ponovo ističe značaj edukacije i prosvećivanja ljudi u cilju promocije vakcinacije za opšte dobro. Sva ova i mnoga druga otvorena pitanja i problemi nameću nove izazove pred naučnike i zdravstvene radnike i njihovo rešenje će sigurno doprineti uspešnoj kontroli ove pandemije, ali će nas i pripremiti da bolje reagujemo u slučaju nekih budućih epidemija i/ili pandemija koje će se, bez ikakve sumnje, javiti pre ili kasnije. Do tada, moja je preporuka da se svi vakcinišu protiv COVID-19 jer, da parafraziram čuvenog profesora Orensteina, jednog od utemeljivača moderne vakcinologije, nisu vakcine te koje spasavaju živote ljudi već je to vakcinacija.

\section{Literatura}

1. World Health Organization. WHO Coronavirus (COVID-19) Dashboard. 2021. (cited 2021. Jul 23) Available from: https://covid19.who.int/.

2. Arya R, Kumari S, Pandey B, Mistry H, Bihani SC, Das A, et al. Structural insights into SARS-CoV-2 proteins. Journal of molecular biology. 2021; 433(2):166725.

3. Kim YM, Shin EC. Type I and III interferon responses in SARSCoV-2 infection. Experimental \& molecular medicine. 2021; 53(5):750-60.

4. Sette A, Crotty S. Adaptive immunity to SARS-CoV-2 and COVID-19. Cell. 2021; 184(4):861-80.

5. Grifoni A, Weiskopf D, Ramirez SI, Mateus J, Dan JM, Moderbacher CR, et al. Targets of T Cell Responses to SARSCoV-2 Coronavirus in Humans with COVID-19 Disease and Unexposed Individuals. Cell. 2020; 181(7):1489-501.e15.

6. Piccoli L, Park YJ, Tortorici MA, Czudnochowski N, Walls AC, Beltramello $M$, et al. Mapping Neutralizing and Immunodominant Sites on the SARS-CoV-2 Spike ReceptorBinding Domain by Structure-Guided High-Resolution Serology. Cell. 2020; 183(4):1024-42.e21.

7. McMahan K, Yu J, Mercado NB, Loos C, Tostanoski LH, Chandrashekar A, et al. Correlates of protection against SARSCoV-2 in rhesus macaques. Nature. 2021; 590(7847):630-4.

8. Addetia A, Crawford KHD, Dingens A, Zhu H, Roychoudhury P, Huang ML, et al. Neutralizing Antibodies Correlate with Protection from SARS-CoV-2 in Humans during a Fishery Vessel Outbreak with a High Attack Rate. Journal of clinical microbiology. 2020; 58(11).

9. Bergwerk M, Gonen T, Lustig Y, Amit S, Lipsitch M, Cohen C, et al. Covid-19 Breakthrough Infections in Vaccinated Health Care Workers. The New England journal of medicine. 2021. Jul 28. doi: 10.1056/NEJMoa2109072. Online ahead of print.

10. Ng KW, Faulkner N, Cornish GH, Rosa A, Harvey R, Hussain S, et al. Preexisting and de novo humoral immunity to SARS-CoV-2 in humans. Science. 2020; 370(6522):1339-43.

11. Alfego D, Sullivan A, Poirier B, Williams J, Adcock D, Letovsky S. A population-based analysis of the longevity of SARS-CoV-2 antibody seropositivity in the United States. EClinicalMedicine. $2021 ; 36: 100902$

12. Turner JS, Kim W, Kalaidina E, Goss CW, Rauseo AM, Schmitz AJ, et al. SARS-CoV-2 infection induces long-lived bone marrow plasma cells in humans. Nature. 2021; 595(7867):421-5.

13. Dan JM, Mateus J, Kato Y, Hastie KM, Yu ED, Faliti CE, et al. Immunological memory to SARS-CoV-2 assessed for up to 8 months after infection. Science. 2021; 371(6529).

14. Wang Z, Muecksch F, Schaefer-Babajew D, Finkin S, Viant C, Gaebler C, et al. Naturally enhanced neutralizing breadth to SARS-CoV-2 after one year. bioRxiv. 2021; 2021.05.07.443175.

15. Jarjour NN, Masopust D, Jameson SC. T Cell Memory: Understanding COVID-19. Immunity. 2021; 54(1):14-8.

16. Baumgarth N, Nikolich-Žugich J, Lee FE, Bhattacharya D. Antibody Responses to SARS-CoV-2: Let's Stick to Known Knowns. Journal of immunology. 2020; 205(9):2342-50.

17. Hall VJ, Foulkes S, Charlett A, Atti A, Monk EJM, Simmons R, et al. SARS-CoV-2 infection rates of antibody-positive compared with antibody-negative health-care workers in England: a large, multicentre, prospective cohort study (SIREN). Lancet. 2021; 397(10283):1459-69.

18. Hansen CH, Michlmayr D, Gubbels SM, Mølbak K, Ethelberg S. Assessment of protection against reinfection with SARSCoV-2 among 4 million PCR-tested individuals in Denmark in 2020: a population-level observational study. Lancet. 2021; 397(10280):1204-12.

19. Subbarao $\mathrm{K}$. The success of SARS-CoV-2 vaccines and challenges ahead. Cell host \& microbe. 2021; 29(7):1111-23.

20. Sadoff J, Gray G, Vandebosch A, Cárdenas V, Shukarev G, Grinsztejn B, et al. Safety and Efficacy of Single-Dose Ad26. COV2.S Vaccine against Covid-19. The New England journal of medicine. 2021; 384(23):2187-201.

21. Danas. Stručni komitet za imunizaciju: Preporuka da građani Srbije šest meseci posle druge, prime treću dozu i to RNK vakcine. 2021. (cited 2021. Jul 26). Available from: https://www.danas. rs/drustvo/preporuka-da-gradjani-srbije-sest-meseci-posle-druge-prime-trecu-dozu-i-to-rnk-vakcine/.

22. Krammer F. SARS-CoV-2 vaccines in development. Nature. 2020; 586(7830):516-27.

23. Rauch S, Jasny E, Schmidt KE, Petsch B. New Vaccine Technologies to Combat Outbreak Situations. Frontiers in immunology. 2018; 9:1963.

24. Lurie N, Saville M, Hatchett R, Halton J. Developing Covid-19 Vaccines at Pandemic Speed. The New England journal of medicine. 2020; 382(21):1969-73.

25. Amanat F, Krammer F. SARS-CoV-2 Vaccines: Status Report. Immunity. 2020; 52(4):583-9.

26. World Health Organization. Draft landscape and tracker of COVID-19 candidate vaccines. 2021. (cited 2021. Jul 27) Available from: https://www.who.int/publications/m/item/ draft-landscape-of-covid-19-candidate-vaccines.

27. Vaccine Centre at the London School of Hygiene \& Tropical Medicine. Vaccine tracker. 2021. (cited 2021. Jul 23). Available from: https://vac-lshtm.shinyapps.io/ncov_vaccine_landscape/.

28. World Health Organization. Status of COVID-19 Vaccines within WHO EUL/PQ evaluation process. 2021. (cited 2021. Jul 23). Available from: https://extranet.who.int/pqweb/sites/default/files/documents/Status_COVID_VAX_15July2021.pdf.

29. Agencija za lekove i medicinska sredstva Srbije. 2021. (cited 2021. Jul 23). Available from: https://www.alims.gov.rs/.

30. Radio Slobodna Evropa. Predsednik Srbije: Modernina vakcina stiže u oktobru. 2021. (cited 2021. Jul 23). Available from: https://www.slobodnaevropa.org/a/srbija-vucic-vakcina-moderna/31359862.html.

31. Baden LR, El Sahly HM, Essink B, Kotloff K, Frey S, Novak R, et, al. Efficacy and Safety of the mRNA-1273 SARS-CoV-2 Vaccine. The New England journal of medicine. 2021; 384(5):403-16. 
32. Polack FP, Thomas SJ, Kitchin N, Absalon J, Gurtman A, Lockhart S, et al. Safety and Efficacy of the BNT162b2 mRNA Covid-19 Vaccine. The New England journal of medicine. 2020; 383(27):2603-15.

33. Logunov DY, Dolzhikova IV, Shcheblyakov DV, Tukhvatulin AI, Zubkova OV, Dzharullaeva AS, et al. Safety and efficacy of an rAd26 and rAd5 vector-based heterologous prime-boost COVID-19 vaccine: an interim analysis of a randomised controlled phase 3 trial in Russia. Lancet. 2021; 397(10275):671-81.

34. Ramasamy MN, Minassian AM, Ewer KJ, Flaxman AL, Folegatti PM, Owens DR, et al. Safety and immunogenicity of ChAdOx1 $\mathrm{nCoV}-19$ vaccine administered in a prime-boost regimen in young and old adults (COV002): a single-blind, randomised, controlled, phase 2/3 trial. Lancet. 2021; 396(10267):1979-93.

35. Voysey M, Clemens SAC, Madhi SA, Weckx LY, Folegatti PM, Aley PK, et al. Safety and efficacy of the ChAdOx1 nCoV-19 vaccine (AZD1222) against SARS-CoV-2: an interim analysis of four randomised controlled trials in Brazil, South Africa, and the UK. Lancet. 2021; 397(10269):99-111.

36. AZD1222 US Phase III primary analysis confirms safety and efficacy. 2021. (cited 2021. Jul 23) Available from: https://www.astrazeneca.com/media-centre/press-releases/2021/azd1222-us-phaseiii-primary-analysis-confirms-safety-and-efficacy.html.

37. Voysey M, Costa Clemens SA, Madhi SA, Weckx LY, Folegatti PM, Aley PK, et al. Single-dose administration and the influence of the timing of the booster dose on immunogenicity and efficacy of ChAdOx1 nCoV-19 (AZD1222) vaccine: a pooled analysis of four randomised trials. Lancet. 2021; 397(10277):881-91.

38. World Health Organization. AstraZeneca ChAdOx1-S/nCoV19 [recombinant], COVID-19 vaccine. 2021. (cited 2021. Jul 23). Available from: https://www.who.int/publications $/ \mathrm{m} /$ item/ chadox1-s-recombinant-covid-19-vaccine.

39. Single dose vaccine, Sputnik Light, authorized for use in Russia. 2021. (cited 2021. Jul 23). Available from: https://sputnikvaccine.com/newsroom/pressreleases/ single-dose-vaccine-sputnik-light-authorized-for-use-in-russia/.

40. Al Kaabi N, Zhang Y, Xia S, Yang Y, Al Qahtani MM, Abdulrazzaq $\mathrm{N}$, et al. Effect of 2 Inactivated SARS-CoV-2 Vaccines on Symptomatic COVID-19 Infection in Adults: A Randomized Clinical Trial. JAMA. 2021; 326(1):35-45.

41. Wang H, Zhang Y, Huang B, Deng W, Quan Y, Wang W, et al. Development of an Inactivated Vaccine Candidate, BBIBPCorV, with Potent Protection against SARS-CoV-2. Cell. 2020; 182(3):713-21.e9.

42. World Health Organization. Interim recommendations for use of the inactivated COVID-19 vaccine BIBP developed by China National Biotec Group (CNBG), Sinopharm. 2021. (cited 2021 Jul 23). Available from: https://www.who.int/publications/i/ item/WHO-2019-nCoV-vaccines-SAGE_recommendation-BIBP-2021.1.

43. Krause P, Fleming TR, Longini I, Henao-Restrepo AM, Peto R. COVID-19 vaccine trials should seek worthwhile efficacy. Lancet. 2020; 396(10253):741-3.

44. Hall VJ, Foulkes S, Saei A, Andrews N, Oguti B, Charlett A, et al COVID-19 vaccine coverage in health-care workers in England and effectiveness of BNT162b2 mRNA vaccine against infection (SIREN): a prospective, multicentre, cohort study. Lancet. 2021; 397(10286):1725-35.

45. Vasileiou E, Simpson CR, Shi T, Kerr S, Agrawal U, Akbari A, et al. Interim findings from first-dose mass COVID-19 vaccination roll-out and COVID-19 hospital admissions in Scotland: a national prospective cohort study. Lancet. 2021; 397(10285):1646-57.

46. Dagan N, Barda N, Kepten E, Miron O, Perchik S, Katz MA, et al. BNT162b2 mRNA Covid-19 Vaccine in a Nationwide Mass Vaccination Setting. The New England journal of medicine. 2021; 384(15):1412-23.

47. Haas EJ, Angulo FJ, McLaughlin JM, Anis E, Singer SR, Khan F, et al. Impact and effectiveness of mRNA BNT162b2 vaccine against SARS-CoV-2 infections and COVID-19 cases, hospitalisations, and deaths following a nationwide vaccination campaign in Israel: an observational study using national surveillance data. Lancet.
2021; 397(10287):1819-29.

48. Menni C, Klaser K, May A, Polidori L, Capdevila J, Louca P, et al. Vaccine side-effects and SARS-CoV-2 infection after vaccination in users of the COVID Symptom Study app in the UK: a prospective observational study. The Lancet Infectious diseases. 2021; 21(7):939-49.

49. Thompson MG, Burgess JL, Naleway AL, Tyner HL, Yoon SK, Meece J, et al. Interim Estimates of Vaccine Effectiveness of BNT162b2 and mRNA-1273 COVID-19 Vaccines in Preventing SARS-CoV-2 Infection Among Health Care Personnel, First Responders, and Other Essential and Frontline Workers - Eight U.S. Locations, December 2020-March 2021. MMWR Morbidity and mortality weekly report. 2021; 70(13):495-500.

50. Levine-Tiefenbrun M, Yelin I, Katz R, Herzel E, Golan Z, Schreiber L, et al. Initial report of decreased SARS-CoV-2 viral load after inoculation with the BNT162b2 vaccine. Nature medicine. 2021; 27(5):790-2.

51. The times of Israel. Israeli, UK data offer mixed signals on vaccine's potency against Delta strain. 2021. (cited 2021. Jul 23). Available from: https://www.timesofisrael.com/israeli-uk-data-offer-mixed-signals-on-vaccines-potency-against-delta-strain/.

52. Lopez Bernal J, Andrews N, Gower C, Gallagher E, Simmons R, Thelwall S, et al. Effectiveness of Covid-19 Vaccines against the B.1.617.2 (Delta) Variant. The New England journal of medicine. 2021. ;NEJMoa2108891. doi: 10.1056/NEJMoa2108891. Online ahead of print.

53. Reuters. Russia’s Sputnik V vaccine $97.6 \%$ effective in real-world study. 2021. (cited 2021. Jul 23). Available from: https://www.reuters.com/article/ health-coronavirus-russia-vaccine-idINL1N2MC1BG.

54. Our World in Data. Coronavirus Pandemic (COVID-19). 2021. (cited 2021. Jul 23). Available from: https://ourworldindata.org/ coronavirus.

55. Klasse PJ, Nixon DF, Moore JP. Immunogenicity of clinically relevant SARS-CoV-2 vaccines in nonhuman primates and humans. Science advances. 2021; 7(12):eabe8065.

56. Mulligan MJ, Lyke KE, Kitchin N, Absalon J, Gurtman A, Lockhart S, et al. Phase I/II study of COVID-19 RNA vaccine BNT162b1 in adults. Nature. 2020; 586(7830):589-93.

57. Xia S, Zhang Y, Wang Y, Wang H, Yang Y, Gao GF, et al. Safety and immunogenicity of an inactivated SARS-CoV-2 vaccine, BBIBPCorV: a randomised, double-blind, placebo-controlled, phase $1 / 2$ trial. The Lancet Infectious diseases. 2021; 21(1):39-51.

58. Logunov DY, Dolzhikova IV, Zubkova OV, Tukhvatulin AI, Shcheblyakov DV, Dzharullaeva AS, et al. Safety and immunogenicity of an rAd26 and rAd5 vector-based heterologous prime-boost COVID-19 vaccine in two formulations: two open, non-randomised phase 1/2 studies from Russia. Lancet. 2020; 396(10255):887-97.

59. Jackson LA, Anderson EJ, Rouphael NG, Roberts PC, Makhene $\mathrm{M}$, Coler RN, et al. An mRNA Vaccine against SARS-CoV-2 Preliminary Report. The New England journal of medicine. 2020; 383(20):1920-31.

60. Folegatti PM, Ewer KJ, Aley PK, Angus B, Becker S, BelijRammerstorfer S, et al. Safety and immunogenicity of the ChAdOx1 nCoV-19 vaccine against SARS-CoV-2: a preliminary report of a phase $1 / 2$, single-blind, randomised controlled trial. Lancet. 2020; 396(10249):467-78.

61. Khoury DS, Cromer D, Reynaldi A, Schlub TE, Wheatley AK, Juno JA, et al. Neutralizing antibody levels are highly predictive of immune protection from symptomatic SARS-CoV-2 infection. Nature medicine. 2021; 27(7):1205-11.

62. Jeewandara C, Aberathna IS, Pushpakumara PD, Kamaladasa A, Guruge D, Jayathilaka D, et al. Antibody and T cell responses to Sinopharm/BBIBP-CorV in naïve and previously infected individuals in Sri Lanka. medRxiv. 2021; 2021.07.15.21260621.

63. Ebinger JE, Fert-Bober J, Printsev I, Wu M, Sun N, Prostko JC, et al. Antibody responses to the BNT162b2 mRNA vaccine in individuals previously infected with SARS-CoV-2. Nature medicine. 2021; 27(6):981-4. 
64. World Health Organization. Coronavirus disease (COVID-19): Vaccines safety. 2021. (cited 2021. Jul 23). Available from: https://www.who.int/news-room/q-a-detail/ coronavirus-disease-(covid-19)-vaccines-safety.

65. Centers for Disease Control and Prevention. Safety of COVID-19 Vaccines. 2021. (cited 2021. Jul 23). Available from: https://www. cdc.gov/coronavirus/2019-ncov/vaccines/safety/safety-of-vaccines.html.

66. United Kingdom Government. Medicines \& Healthcare products Regulatory Agency. Coronavirus vaccine - weekly summary of Yellow Card reporting. 2021. (cited 2021. Jul 23). Available from: https://www.gov.uk/government/publications/coronavirus-covid-19-vaccine-adverse-reactions/ coronavirus-vaccine-summary-of-yellow-card-reporting.

67. European Medicines Agency. Vaxzevria (previously COVID-19 Vaccine AstraZeneca). 2021. (cited 2021. Jul 23). Available from: https://www.ema.europa.eu/en/medicines/human/EPAR/ vaxzevria-previously-covid-19-vaccine-astrazeneca.

68. Cines DB, Bussel JB. SARS-CoV-2 Vaccine-Induced Immune Thrombotic Thrombocytopenia. The New England journal of medicine. 2021; 384(23):2254-6.

69. Greinacher A, Thiele T, Warkentin TE, Weisser K, Kyrle PA, Eichinger S. Thrombotic Thrombocytopenia after ChAdOx1 nCov-19 Vaccination. The New England journal of medicine. 2021; 384(22):2092-101.

70. World Health Oraganization. Global Advisory Committee on Vaccine Safety (GACVS) review of latest evidence of rare adverse blood coagulation events with AstraZeneca COVID-19 Vaccine (Vaxzevria and Covishield) . 2021. (cited 2021. Jul 23). Available from: https://www.who.int/news/item/16-04-2021-global-advisory-committee-on-vaccine-safety-(gacvs)-review-of-latest-evidence-of-rare-adverse-blood-coagulation-events-with-astrazeneca-covid-19-vaccine-(vaxzevria-and-covishield).

71. Wu F, Zhao S, Yu B, Chen YM, Wang W, Song ZG, et al. A new coronavirus associated with human respiratory disease in China. Nature. 2020; 579(7798):265-9.

72. Korber B, Fischer WM, Gnanakaran S, Yoon H, Theiler J, Abfalterer W, et al. Tracking Changes in SARS-CoV-2 Spike: Evidence that D614G Increases Infectivity of the COVID-19 Virus. Cell. 2020; 182(4):812-27.e19.

73. World Health Organization: COVID-19 Weekly Epidemiological Update, 25 February 2021 [updated 25 February 2021. 2021. (cited 2021. Jul 23). Available from: https://apps.who.int/iris/ handle/10665/339859.

74. World Health Organization: Tracking SARS-CoV-2 variants. 2021. (cited 2021. Jul 23). Available from: https://www.who.int/ en/activities/tracking-SARS-CoV-2-variants/.

75. Wibmer CK, Ayres F, Hermanus T, Madzivhandila M, Kgagudi P, Oosthuysen B, et al. SARS-CoV-2 501Y.V2 escapes neutralization by South African COVID-19 donor plasma. Nature medicine. 2021; 27(4):622-5.

76. Motozono C, Toyoda M, Zahradnik J, Saito A, Nasser H, Tan TS, et al. SARS-CoV-2 spike L452R variant evades cellular immunity and increases infectivity. Cell host \& microbe. 2021; 29(7):112436.e11.

77. Fontanet A, Autran B, Lina B, Kieny MP, Karim SSA, Sridhar D. SARS-CoV-2 variants and ending the COVID-19 pandemic Lancet. 2021; 397(10278):952-4.

78. Abu-Raddad LJ, Chemaitelly $\mathrm{H}$, Butt AA. Effectiveness of the BNT162b2 Covid-19 Vaccine against the B.1.1.7 and B.1.351 Variants. The New England journal of medicine. 2021; 385(2):187-9.

79. Madhi SA, Baillie V, Cutland CL, Voysey M, Koen AL, Fairlie L, et al. Efficacy of the ChAdOx1 nCoV-19 Covid-19 Vaccine against the B.1.351 Variant. The New England journal of medicine. 2021; 384(20):1885-98.

80. European Centre for Disease Prevention and Control. Assessing SARS-CoV-2 circulation, variants of concern, non-pharmaceutical interventions and vaccine rollout in the EU/EEA, 15th update - 10 June 2021. ECDC: Stockholm; 2021.
81. European Centre for Disease Prevention and Control. Implications for the EU/EEA on the spread of the SARSCoV-2 Delta (B.1.617.2) variant of concern - 23 June 2021. ECDC: Stockholm; 2021.

82. Lustig Y, Zuckerman N, Nemet I, Atari N, Kliker L, Regev-Yochay G, et al. Neutralising capacity against Delta (B.1.617.2) and other variants of concern following Comirnaty (BNT162b2, BioNTech/ Pfizer) vaccination in health care workers, Israel. Euro surveillance. $2021 ; 26(26)$.

83. Planas D, Veyer D, Baidaliuk A, Staropoli I, Guivel-Benhassine F, Rajah MM, et al. Reduced sensitivity of SARS-CoV-2 variant Delta to antibody neutralization. Nature. 2021; 596:276-80.

84. Brown CM, Vostok J, Johnson H, Burns M, Gharpure R, Sami S, et al. Outbreak of SARS-CoV-2 Infections, Including COVID-19 Vaccine Breakthrough Infections, Associated with Large Public Gatherings - Barnstable County, Massachusetts, July 2021. MMWR Morb Mortal Wkly Rep. 2021; 70:1059.

85. Krause PR, Fleming TR, Longini IM, Peto R, Briand S, Heymann DL, et al. SARS-CoV-2 Variants and Vaccines. The New England journal of medicine. 2021; 385(2):179-86.

86. Doria-Rose N, Suthar MS, Makowski M, O'Connell S, McDermott AB, Flach B, et al. Antibody Persistence through 6 Months after the Second Dose of mRNA-1273 Vaccine for Covid-19. The New England journal of medicine. 2021; 384(23):2259-61.

87. Pfizer. Pfizer and Biontech confirm high efficacy and no serious safety concerns through up to six months following second dose in updated topline analysis of landmark COVID-19 vaccine study. 2021. (cited 2021. Jul 23). Available from: https:// www.pfizer.com/news/press-release/press-release-detail/ pfizer-and-biontech-confirm-high-efficacy-and-no-serious.

88. Hacisuleyman E, Hale C, Saito Y, Blachere NE, Bergh M, Conlon EG, et al. Vaccine Breakthrough Infections with SARSCoV-2 Variants. The New England journal of medicine. 2021; 384(23):2212-8.

89. COVID-19 Vaccine Breakthrough Infections Reported to CDC United States, January 1-April 30, 2021. MMWR Morbidity and mortality weekly report. 2021; 70(21):792-3.

90. European Centre for Disease Prevention and Control. COVID-19 vaccine effectiveness - real-world evidence. 2021. (cited 2021. Jul 23). Available from: https://www.ecdc.europa.eu/en/covid-19/ latest-evidence/vaccines.

91. Centers for Disease Control and Prevention. COVID-19 Vaccine Breakthrough Case Investigation and Reporting. 2021. (cited 2021. Jul 23). Available from: https://www.cdc.gov/vaccines/covid-19/health-departments/breakthrough-cases.html.

92. Callaway E. Mix-and-match COVID vaccines trigger potent immune response. Nature. 2021; 593(7860):491.

93. Barros-Martins J, Hammerschmidt SI, Cossmann A, Odak I, Stankov MV, Morillas Ramos G, et al. Immune responses against SARS-CoV-2 variants after heterologous and homologous ChAdOx1 nCoV-19/BNT162b2 vaccination. Nature medicine. 2021. Jul 14. doi: 10.1038/s41591-021-01449-9. Online ahead of print.

94. Borobia AM, Carcas AJ, Pérez Olmeda, Teresa M, Castaño L, Jesús Bertrán M, et al. Reactogenicity and Immunogenicity of BNT162b2 in Subjects Having Received a First Dose of ChAdOx1s: Initial Results of a Randomised, Adaptive, Phase 2 Trial (CombiVacS). Available from: https://ssrn.com/abstract=3854768 ili http://dx.doi.org/10.2139/ssrn.3854768.

95. Shaw RH, Stuart A, Greenland M, Liu X, Nguyen Van-Tam JS, Snape MD. Heterologous prime-boost COVID-19 vaccination: initial reactogenicity data. Lancet. 2021; 397(10289):2043-6.

96. Liu X, Shaw RH, Stuart AS, Greenland M, Dinesh T, ProvstgaardMorys S, et al. Safety and Immunogenicity Report from the Com-COV Study - a Single-Blind Randomised Non-Inferiority Trial Comparing Heterologous And Homologous Prime-Boost Schedules with An Adenoviral Vectored and mRNA COVID-19 Vaccine. Available from: SSRN: https://ssrn.com/abstract=3874014 ili http://dx.doi.org/10.2139/ssrn.3874014. 